$$
\text { \#11323 }
$$

by Jurnal Inovasi Hasil Pengabdian Masyarakat (jipemas)

Submission date: 12-Dec-2021 11:07PM (UTC+0700)

Submission ID: 1728163430

File name: 11323.pdf (324.85K)

Word count: 3435

Character count: 21544 


\title{
Pemanfaatan pekarangan dan limbah rumah tangga untuk budidaya lele sebagai upaya memenuhi pangan keluarga selama pandemi covid-19
}

\author{
Aprilia Sufi Subiastuti ${ }^{1 *}$, Budi Setiadi Daryono ${ }^{2}$ Sukirno $^{3}$ \\ 'Universitas Gadjah Mada, Yogyakarta, Indonesia, email: apriliasufi@ugm.ac.id \\ ${ }^{2}$ Universitas Gadjah Mada, Yogyakarta, Indonesia, email: sukirnobiougm@ugm.ac.id \\ 3Universitas Gadjah Mada, Yogyakarta, Indonesia, email: bs_daryono@mail.ugm.ac.id \\ *Koresponden penulis
}

\section{Info Artikel}

Diajukan: 2021-06-27

Diterima: 2021-11-01

Diterbitkan: -

Keywords:

portable pool; aquaponics; alternative fish feed

Kata Kunci:

kolam portabel; aquaponik; pakan altematif

\section{()ㅇ (1) (-) \\ Lisensi: cc-by-sa \\ Copyright @ 2022 Aprilla Sufi Subiastuti, Budi Setiadi Daryono,} Sukirno

\begin{abstract}
The Covid-19 pandemic has caused changes in the socio-economic conditions of the Indonesian people. Around $40 \%$ of workers or business actors experience a change in income. Indirectly, this affects the community's ability to meet the family's food needs. This community service program aimed to provide education to the community to optimize the use of yard and household waste to meet family food needs through catfish cultivation. The program implementation was divided into three stages, i.e community training, mentoring, and evaluation. Community training includes training on hydroponic catfish and kale cultivation using pots and training on making cattish feed and probiotic from household waste. Assistance was carried out regularly every week until the catfish can be harvested. An evaluation was carried out at the end of the activity to determine the effectiveness and potential of the technology to be commercialized. The results of this program show that the cultivation of catfish and kale using pots can be used to meet the family's food needs at low prices. The design technology of portable pool from plastic pot also had the potential to be developed as a home industry. Catfish feed from household waste can reduce feed costs in catfish cultivation by up to $20 \%$ with an food conversion ratio FCR value of 1.11 dan feed efficiency $90 \%$. This catfish feed helps reduce food waste and kitchen waste by up to $100 \%$.
\end{abstract}

\begin{tabular}{l} 
Abstrak \\
Pandemi Covid-19 menyebabkan perubahan kondisi sosial ekonomi \\
masyarakat Indonesia. Sekitar 40\% pekerja atau pelaku usaha \\
mengalami perubahan pendapatan. Hal ini sedikit banyak \\
mempengaruhi kemampuan masyarakat dalam memenuhi kebutuhan \\
pangan keluarga. Pengabdian masyarakat ini bertujuan untuk \\
memberikan edukasi kepada masyarakat untuk mengoptimalkan \\
pemanfaatan pekarangan dan limbah rumah tangga untuk memenuhi \\
kebutuhan pangan keluarga melalui budidaya lele. Pelaksanaan \\
program dibagi ke dalam tiga tahap, yaitu pelatihan warga, \\
pendampingan, dan evaluasi.Pelatihan warga meliputi pelatihan \\
budidaya lele dan kangkung secara hidroponik menggunakan pot dan \\
pelatihan pembuatan pakan lele dari limbah rumah tangga. \\
Pendampingan dilakukan secara berkala setiap minggu hingga lele \\
bisa dipanen. Evaluasi dilakukan di akhir kegiatan untuk mengetahui \\
efektivitas dan potensi teknologi untuk dikomersilkan. Hasil dari \\
program ini menunjukkan bahwa budidaya lele dan kangkung \\
menggunakan pot dapat digunakan untuk memenuhi kebutuhan \\
\hline
\end{tabular}


pangan keluarga dengan harga yang murah. Desain teknologi kolam portabel dari pot ini juga berpotensi untuk dikembangkan sebagai industri rumah tangga. Pakan lele dari limbah rumah tangga mampu menekan biaya pakan dalam budidaya lele hingga $20 \%$ dengan nilai rasio konversi pakan (FCR) sebesar 1.11 atau efisiens pakan hingga 90\%. Pakan lele ini membantu pengurangan sampah sisa makanan dan sampah dapur hingga $100 \%$.

Cara mensitasi artikel:

Subiastuti, A. S., Daryono, B. S., \& Sukirno. (2022). Pemanfaatan pekarangan dan limbah rumah tangga untuk budidaya lele sebagai upaya memenuhi pangan keluarga selama pandemi covid-19. Jurnal Inovasi Hasi Pengabdian Masyarakat (JIPEMAS), 5(1), 1-10. https://doi.org/10.33474/jipemas.v5i1.11323

\section{PENDAHULUAN}

Terhitung sejak Maret 2020, pandemi Covid-19 mulai melanda Indonesia dan mengubah berbagai sektor kehidupan niasyarakat. Kebijakan pemerintah untuk membatasi penyebaran wabah Covid-19 dengan menerapkan Pembatasan Sosial Berskala Besar (PSBB) menyebabkan perubahan pola interaksi masyarakat, pola konsumsi, dan kemampuan ekonomi (Yanuarita \& Haryati, 2020). Disisi lain, pembatasan aktivitas industri dan pertumbuhan ekonomi yang minus menyebabkan banyak masyarakat yang mengalami penurunan pendapatan, baik akibat penurunan omset usaha maupun pemberhentian hubungan kerja (PHK). Sejumlah 15,6\% pekerja mengalami PHK atau dirumahkan sejak April 2020 dan $40 \%$ pekerja mengalami penurunan pendapatan hingga 50\% dibandingkan sebelum pafidemi (Irawan et al., 2015). Hal ini lebih jauh akan menyebabkan menurunnya daya beli dan akses rumah tangga terhadap pangan. Bagi kelompok pendapatan menengah ke atas, mungkin tidak terjadi perubahan volume pangan namun hanya berdampak pada variasi jenis dan cara memperoleh pangan. Namun bagi masyarakat berpendapatan rendah, hal ini akan berpengaruh terhadap volume dan jenis pangan yang dikonsumsi (Yamali \& Putri, 2020).

Data Kementerian Pertanian tahun 2016 menunjukkan bahwa pola konsumsi pangan rata-rata Sebagian penduduk Indonesia belum sesuai dengan rekomendasi standar kecukupan komposisi zat gizi, dimana konsumsi sumber karbohidrat melebihi standar sedangkan konsumsi buah, sayur, dan protein hewani masihdllawah standar kecukupan (Ariani \& Hermanto, 2015; Suryani et al., 2016). Dalam hal ini, konsumsi pangan sumber karbohidrat melebihi standar kecukupan, namun untuk konsumsi sayur dan buah serta pangan sumber protein hewani masih kurang dari standar kecukupan. Oleh karena itu, salah satu upaya untuk memenuh 1Rebutuhan gizi pangan keluarga di era pandemi Covid-19 dapat dilakukan optimalisasi pemanfaatan lahan pekarangan untuk sarana penyediaan pangan rumah tangga.

Pekarangan merupakan warisan budaya bangsa Indonesia yang memiliki banyak fungsi, meliputi sumber pangan, penghasil kayu, komoditas perdagangan, rempah-rempah, obat-obatan, bahan baku kerajinan, tanaman hias, dan fungsi sosial (Junaidah et al., 2016). Pemanfaatan pekarangan untuk budidaya tanaman sayur, budidaya ikan, dan atau budidaya ternak dapat membantu penyediaan pangan keluarga sekaligus mengurangi pengeluaran. 
Bahkan budidaya tanaman maupun hewan di pekarangan rumah ini juga dapat menambah penghasilan keluarga jika diperoleh hasil yang berlebih.

Model pemanfaatan pekarangan rumah ini juga telah berlangsung sejak lama serta telah menjadi program pemerinta 1. Pada tahun 1991, pemerintah melalui Departemen Pertanian mendorong pemanfaatan pekarangan untuk diversifikasi konsumsi melalui program Diversifikasi Pangan dan Gizi (DPG). Pada tahun 2009, Badan Ketahanan Pangan (BKP) mengawali program optimalisasi pemanfaatan pekarangan dengan sasaran daerah miskin atau rawan pangan. Pada tahun 2011, Badan Penelitian dan Pengembangan Pertanian (Balitbangtan) Kementerian Pertanian mincanangkan program Model Kawasan Rumah Pangan Lestari (M-KRPL) dengan jumlah capaian $1.450 \mathrm{M}-\mathrm{KRPL}$ di seluruh provinsi Indonesia. Tahun 2012, M-KRPL berubah menjadi program KRPL, yang mendukung ketahanan dan kemandirian pangan keluarga, diversifikasi pangan berbasis sumber daya lokal, konservasi tanaman pangan 1 ntuk masa depan, dan peningkatan kesejahteraan keluarga. Selama tahun 2015-2019, program KRPL telah dikembangkan sekitar 13.209 Kelompok Wanita Tani (KWT) di seluruh Indonesia, baik di perkotaan, perdesaan, atau peri-urban (Suryani et al., 2020).

Program Pengabdian Masyarakat ini bertujuan untuk memberikan edukasi kepada masyarakat daerah perkotaan tentang budidaya kangkung dan ternak lele menggunakan kolam portabel yang dapat dilakukan di pekarangan rumah. Lele dan kangkung dipilih sebagai model dalam budidaya ini karena teknik budidayanya yang mudah dan waktu panen yang relatif singkat. Selain itu, lele memiliki kandungan protein yang tinggi sedangkan kangkung memiliki kandungan gizi yang baik. Keduanya juga merupakan bahan pangan yang mudah diolah dan banyak dikonsumsi oleh warga. Lebih lanjut, program ini juga untuk meningkatkan kemampuan masyarakat dalam memenuhi kebutuhan pangan keluarga selama pembatasan sosial akibat pandemi Covid-19. Program ini menawarkan konsep budidaya aquaponik minimalis dalam skala Rumah Tangga serta diversifikasi pangan dengan menggunakan komoditas dan teknologi unggulan pengembangan Universitas Gadjah Mada.

\section{METODE PELAKSANAAN}

Program pengabdian masyarakat ini dilakukan di Dusun Gejayan, Kelurahan Condongcatur, Kecamatan Depok, Kabupaten Sleman, D.I Yogyakarta. Padukuhan Gejayan, Kelurahan Condongcatur merupakan mitra binaan Fakultas Biologi UGM sejak tahun 2015, khususnya untuk diseminasi teknologi hasil penelitian. Pelaksanaan program berlangsung dari bulan Juli Desember 2020. Tahapan pelaksanaan terdiri atas 3 tahap, yaitu pelatihan warga, pendampingan, dan evaluasi.

Penyuluhan kepada masyarakat dilakukan dalam 3 tahap. Tahap pertama dilaksanakan pada bulan Juli 2020 dengan agenda pengenalan program dan rencana kegiatan. Tahap kedua merupakan pelatihan warga tentang teknologi budidaya kangkung secara aquaponik di dalam pot dan teknologi ternak lele secara tumpangsari di dalam pot yang dilaksanakan tanggal 5 Agustus 2020. 
Tahap ketiga merupakan pelatihan warga tentang teknologi pembuatan pakan lele dan probiotik dari limbah rumah tangga yang dilaksanakan pada 29 Agustus 2020. Pada sosialisasi tahap ketiga ini, masyarakat diberi bantuan berupa 50 kolam portabel dari pot, 2500 ekor benih lele, benih kangkung, dan $10 \mathrm{~L}$ pakan alternatif untuk budidaya lele.

Pendampingan dilakukan dengan melakukan supervisi setiap minggu ke lahan masyarakat yang digunakan untuk budidaya kangkung dan lele. Pada sesi ini masyarakat akan ditanya terkait kendala yang dialami dan diberi solusi untuk penyelesaiannya. Pada minggu ketiga dan keenam, dilakukan pengecekan kondisi air dan pertumbuhan lele. Sebagai perbandingan efektivitas teknologi budidaya dan pakan alternatif, dilakukan pula budidaya lele menggunakan pakan komersial. Uji banding efektivitas dilakukan dengan melakukan budidaya dengan pakan alternatif sebanyak 35 pot dan pakan komersial 15 pot. Hasil panen lele dari kedua perlakuan budidaya dengan pakan berbeda tersebut kemudian dibandingkan nilai FCR dan jumlah total ikan yang berhasil dipanen. Selain itu, 2eberapa perwakilan masyarakat yang tergabung dalam KWT diminta untuk membuat pakan lele alternatif dari limbah rumah tangga dan dievaluasi hasilnya secara berkala.

Pada bulan Desember 2020, dilakukan pemanenan kangkung dan lele dari kolam portabel. Hasil panen digunakan sebagai evaluasi keberlanjutan program. Pada sesi ini juga dilakukan dengar pendapat dari masyarakat terkait pelaksanaan program dan potensi teknologi yang ditawarkan.

\section{HASIL DAN PEMBAHASAN}

\section{Teknologi budidaya kangkung dan lele menggunakan pot/kolam portable}

Kegiatan pengabdian masyarakat diawali dengan koordinasi dengan kepala dusun setempat terkait rencana program yang akan dilakukan. Setelah mendapat persetujuan dari kepala dusun maka dilanjutkan dengan sosialisasi pelaksanaan program kepada masyarakat Dusun Gejayan. Terdapat sekitar 25 warga yang terlibat dalam acara ini, yang terdiri dari ibu-ibu anggota KWT, pemuda karang taruna, dan perwakilan RT setempat. Dusun Gejayan dipilih karena lokasinya terletak di area semi-urban yang rata-rata masyarakatnya merupakan pemilik usaha kos-kosan yang ekonominya terdampak akibat pandemi Covid-19. Selain itu, masyarakat dusun ini memiliki waktu lebih banyak di rumah serta memiliki lahan pekarangan dengan luas sekitar $10-30 \mathrm{M}^{2}$.

Teknologi yang diperkenalkan kepada masyarakat adalah teknologi budidaya lele di dalam kolam portabel. Teknologi ini digunakan untuk memanfaatkan pekarangan rumah untuk budidaya ikan lele dipadukan dengan budidaya tanaman kangkung secara hidroponik dengan harapan dapat meningkatkan nilai ekonomi keluarga. Dalam program ini, ikan lele dipilih sebagai objek budidaya karena memiliki kandungan protein yang tinggi dan memiliki rasa daging yang lezat. Selain itu, budidaya lele memerlukan modal yang relatif kecil, mudah proses pemeliharaanya, tidak 
memerlukan lahan khusus, tidak memerlukan air dalam jumlah banyak, dan pertumbuhannya cepat (Su'udi \& Wathon, 2018).

Kolam portabel yang digunakan pada teknologi ini terbuat dari pot plastik berukuran $50 \mathrm{~L}$ yang dimodifikasi dengan diberi pipa pengatur jumlah air di bagian bawahnya. Pipa tersebut berfungsi untuk menyesuaikan volume air didalam pot dan untuk melakukan pengurasan residu pangan yang mengendap di dasar kolam. Pot tersebut dipilih karena dasarnya (bagian dalam) berbentuk mengerucut sehingga sisa pakan dan kotoran lele dapat mengumpul pada bagian bawah pot dan mudah dibuang (Gambar 1). Menurut Rachmawati et al. (2015) sisa pakan dan sisa metabolisme ikan lele yang mengendap di dasar kolam akan menyebabkan tingginya kadar amoniak dalam air. Semakin tinggi amoniak maka semakin rendah nilai kandungan oksigen dalam air. Kandungan amoniak yang tinggi juga berpotensi menyebabkan kerusakan insang sehingga mengganggu pertumbuhan dan produktivitas lele. Oleh karena itu, perlu dilakukan pengukuran parameter kualitas air dan penggantian air kolam secara berkala

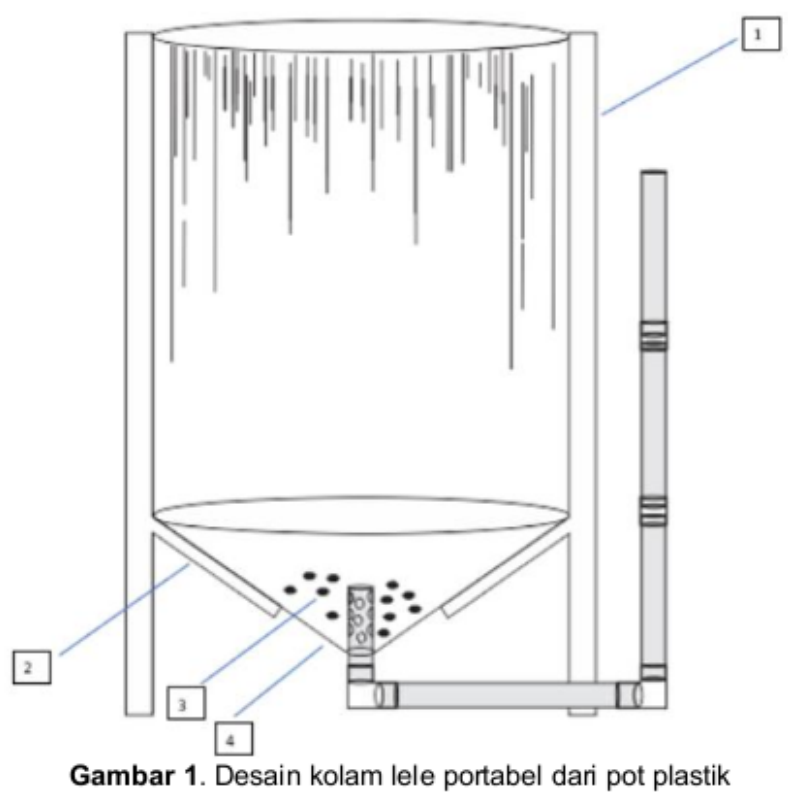

Selain digunakan untuk budidaya lele kolam portabel juga digunakan untuk penanaman tanaman sayur (kangkung) secara hidroponik sehingga mengoptimalkan fungsi kolam portabel dari pot (Gambar 2). Tanaman kangkung dipilih karena batang utama kangkung dapat selalu menumbuhkan daun secara terus menerus setelah dipanen. Keberadaan tanaman kangkung di permukaan kolam sekaligus dapat mempertahankan suhu kolam agar tidak terlalu panas karena adanya naungan serta meminimalisir masuknya kontaminan ke dalam air (Rosalina, 2014). 
Pada kegiatan pengabdian masyarakat ini, digunakan 100 pot/ kolam portabel. Di awal kegiatan, setiap pot diisi dengan $40 \mathrm{~L}$ air, 15-20 ekor benih lele, dan 5-7 tanaman kangkung (seedling). Estimasi waktu budidaya lele dari pembenihan hingga panen kurang lebih 2-3 bulan tergantung ukuran lele yang dikehendaki ketika panen. Pasar biasanya lebih menyukai lele yang berukuran tidak terlalu besar sehingga rasa dagingnya tidak terlalu amis. Dari segi biaya, teknologi budidaya ini memerlukan biaya kurang lebih Rp 100.000 ,- dengan $75 \%$ merupakan belanja modal pot dan sisanya biaya benih lele dan kangkung. Pada kegiatan ini, masyarakat setempat telah diberi bantuan berupa 100 kolam portabel sehingga tidak memerlukan mahal untuk keberlanjutan program ini. Teknologi ini dinilai cukup berhasil sebagai strategi pemenuhan pangan keluarga. Hal ini didasarkan pada hasil panen yang dilakukan pada awal Desember 2020 yang mana tiap kolam dapat menghasilkan 2-3 kg ikan lele atau sekitar 15 ekor lele dewasa, dan 4-6 tanaman kangkung.

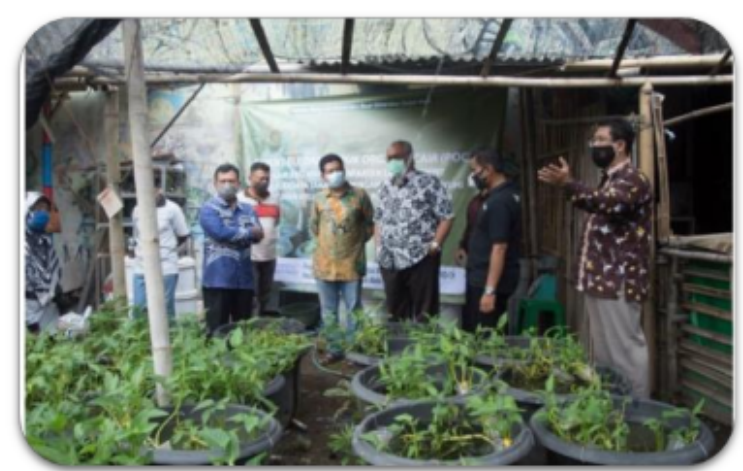

Gambar 2. Pemanenan hasil budidaya lele dan tanaman kangkung hidroponik menggunakan kolam portabel dari pot plastik

\section{Teknologi pembuatan pakan lele alternatif dan probiotik dengan memanfaatkan limbah rumah tangga}

Teknologi kedua yang disosialisasikan kepada masyarakat adalah pemanfaatan limbah rumah tangga untuk pakan lele. Limbah yang digunakan adalah sampah organik sisa makanan atau sampah dapur. Sosialisasi teknologi ke masyarakat dilakukan dalam dua tahap, yaitu melalui pelatihan dan pendampingan berkala. Kegiatan dilakukan secara luring dengan penerapan protokol kesehatan ketat.

Proses pembuatan pakan lele alternatif diawali dengan mengumpulkan sampah sisa makanan dan sampah dapur di suatu ember tertutup. Sampah ditambah nasi katul/tepung ikan dengan rasio 2:1 untuk kemudian difermentasi dengan menambahkan EM4 dengan rasio 1 sendok makan (sdm) EM4 untuk 1 ember sampah organik ukuran $15 \mathrm{~L}$. Setelah 5 hari, hasil fermentasi dipanen kemudian dicetak menjadi bentuk pelet menggunakan saringan (Gambar 3). Menurut Dewi \&3Tahapari (2017) pakan merupakan faktor penentu dalam budidaya ikan lele. Biaya 
pembelian pakan mencapai $80 \%$ biaya operasional budidaya ikan lele. Pelet pakan alternatif ini kemudian dijemur hingga kering. Keunggulan dari pakan alternatif ini adalah dapat mengurangi biaya pemeliharaan lele karena dapat mengurangi biaya pembelian pakan hingga $20 \%$. Selain itu, teknologi ini membantu mengurangi jumlah sampah sisa makanan dan atau sampah dapur hingga nol (zero waste).

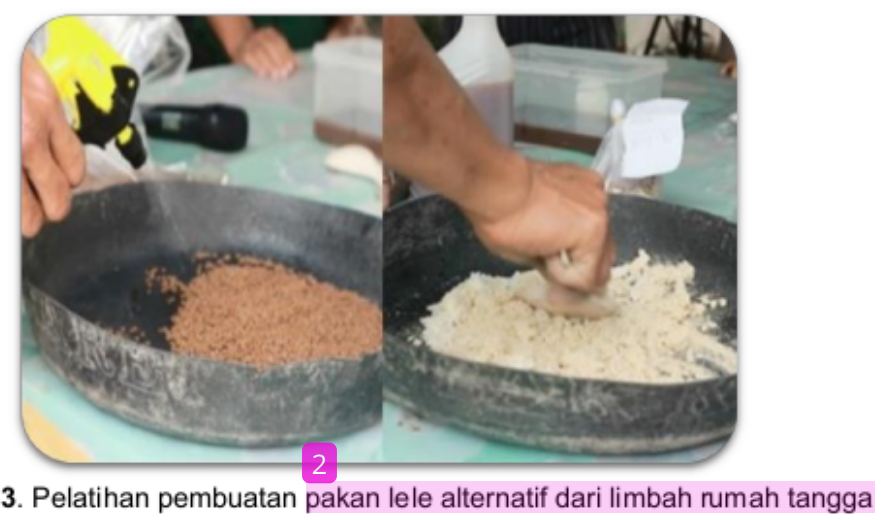

Selain memperoleh pelatihan pembuatan pakan lele alternatif, masyarakat juga diberi pelatihan pembuatan probiotik untuk ikan lele (gambar 4). Probiotik didefinisikan sebagai mikrobia hidup yang berfungsi sebagai pangan aditif dan memiliki efek menguntungkan bagi organisme inang. Penambahan probiotik dalam diet akan memodifikasi komunitas mikrobia saluran cerna, meningkatkan efisiensi penggunaan dan penyerapan nilai gizi pakan, serta meningkatkan respon ketahanan inang terhadap penyakit (Verschuere et al., 2000). Probiotik dalam akuakultur dapat dianggap sebagai komponen hidup atau mati sel mikroba yang (3) berikan secara langsung atau melalui pakan ke dalam air pemeliharaan yang memberikan dampak menguntungkan bagi ikan yang dibudidayakan melalui penyeimbangan komunitas mikrobia di lingkungan (Merrifield et al., 2010).

Pembuatan probiotik dalam program ini dilakukan dengan mencampur air bersama bekatul atau tepung ikan, susu kental manis, yogurt, molase, ragi tape, dan EM4 dengan rasio berturut-turut $3: 1: 1: 0,25: 1$. Campuran tersebut kemudian difermentasi selama 7 hari hingga cairan berwarna coklat. Fermentasi dilakukan di dalam jerigen tertutup berukuran $10 \mathrm{~L}$. Tutup jerigen dibuka setiap dua hari sekali untuk mengeluarkan gas hasil fermentasi, kemudian ditutup kembali. Keunggulan dari probiotik ini adalah biaya pembuatannya relatif murah dibanding probiotik komersial. Probiotik yang dibuat sendiri ini hanya memerlukan biaya Rp 2000 per liter sedangkan probiotik komersial harganya mencapai Rp 25.000 - Rp 172.000 per liter tergantung efektifitas masing-masing merek. Selain itu, probiotik yang dibuat dalam program ini memiliki nilai FCR sebesar $90 \%$, yang artinya $1 \mathrm{~kg}$ pakan menghasilkan pertambahan 
bobot daging ikan lele hingga 900 gram. Dilihat dari nilai efisiensi pakan (1/FCR) maka penggunaan pakan alternatif dan probiotik mencapai $90 \%$. Hal ini sesuai dengan penelitian Faqih dan Arifin (2017) bahwa penggunaan pakan alternatif dan probiotik dalam budidaya lele dapat menghasilkan nilai FCR hingga 1,26 dan nilai efisiensi pakan hingga $80 \%$.

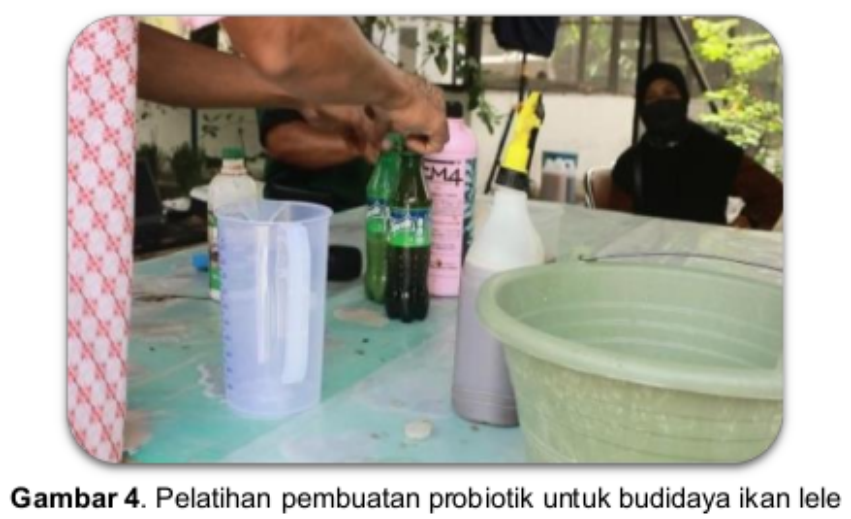

Penggunaan probiotik pada budidaya ikan telah banyak dilakukan bahkan telah masuk ke dalam manajemen budidaya ikan (Dewi \& Tahapari, 2017). Pada budidaya ikan lele mutiara, penambahan probiotik dengan dosis $15 \mathrm{ml} / \mathrm{kg}$ pakan diketahui mampu meningkatkan pertumbuhan panjang mutlak, kelangsungan hidup ikan, nilai FCR, dan pertumbuhan bobot harian atau specific growth rate (SGR) (Apriani \& Putri, 2021). Menurut Yulianingrum et al. (2015) penambahan probiotik meningkatkan pertumbuhan spesifik sebesar 8,023, tingkat kelangsungan hidup hingga $92,62 \%$, efisiensi pakan sebesar $117,22 \%$, serta nilai FCR hingga $85 \%$. Hasil serupa juga dilaporkan oleh Dewi \& Tahapari (2017) bahwa penambahan probiotik komersial terbukti retensi karbohidrat, protein, dan lemak berturut-turut sebesar $10,26 \%, 1,02 \%$, dan $3,22 \%$. Penggunaan probiotik juga dapat menekan biaya hingga $\mathrm{Rp} 561,00 / \mathrm{kg}$ dan meningkatkan keuntungan sebesar $5 \%$.

Hasil dari program pengabdian masyarakat ini diharapkan dapat meningkatkan inovasi warga dalam memanfaatkan pekarangan rumah untuk memenuhi kebutuhan pangan sehari-hari. Selain itu juga mampu meningkatkan keterampilan warga dalam pengolahan limbah rumah tangga menjadi produk yang bernilai ekonomi.

\section{KESIMPULAN}

Teknologi budidaya ikan lele menggunakan pot portabel dan pembuatan pakan alternatif dari limbah rumah tangga telah dapat memberikan keterampilan pada masyarakat Dusun Gejayan untuk memenuhi kebutuhan pangan keluarga. Penggunaan pot portabel membuat masyarakat dapat membudidayakan ikan lele secara cepat dalam skala rumah tangga. Penggunaan pakan alternatif dari limbah rumah tangga dalam budidaya ikan 
lele berhasil menekan biaya pakan hingga 20\% dan memperoleh hasil panen hingga 15 ekor lele berukuran sedang. Masyarakat juga memiliki kemampuan mengolah limbah rumah tangga menjadi pakan alternatif dan probiotik yang berpotensi dikembangkan sebagai industri rumah tangga (IRT). Program ini perlu dilanjutkan dengan pendampingan kepada masyarakat untuk mengembangkan kelompok industri rumah tangga yang menjual pot portabel, pakan alternatif dari limbah rumah tangga, dan atau probiotik untuk budidaya lele.

\section{UCAPAN TERIMA KASIH}

Penulis mengucapkan terima kasih kepada Universitas Gadja2 Mada yang memberikan dana untuk pelaksanaan program ini melalui Hibah Program Penelitian Pemandatan untuk Mitigasi dan Penanganan Covid-19 Tahun Anggaran 2020 (Surat Tugas No. 4091/UN1/DITLIT/DIT-LIT/PT/2020). Ucapan terimakasih juga ditujukan kepada Dewan Guru Besar UGM, Kepala Desa/Lurah Condongcatur, Kepala Dusun Gejayan, KWT Dusun Gejayan, dan Tim Gama Melon Fakultas Biologi UGM atas dukungannya dalam pelaksanaan pengabdian masyarakat ini.

\section{DAFTAR RUJUKAN}

Apriani, I., \& Putri, E. T. (2021). Pengaruh Probiotik pada Pakan Terhadap Pertumbuhan dan Kelangsungan Hidup Ikan Lele Mutiara (Clarias gariepinus) Budidaya Sistem Bioflok. Jurnal Ruaya : Jurnal Penelitian Dan Kajian IImu Perikanan Dan Kelautan, 9(1), 49-53. https://doi.org/10.29406/jr.v9i1.2610

Ariani, M., \& Hermanto. (2015). Dinamika Konsumsi Pangan. In Panel Petani Nasional: Rekonstruksi Agenda Peningkatan Kesejahteraan Petani (pp. 101-123).

Dewi, R. R. S. P. S., \& Tahapari, E. (2017). Pemanfaatan Probiotik Komersial pada Pembesaran Ikan Lele (Clarias gariepinus). Jurnal Riset Akuakultur, 12(3), 275-281. https://doi.org/10.15578/jra.12.3.2017.275-281

Irawan, B., Ariningsih, E., \& Pasandaran, E. (2015). Panel Petani Nasional: Rekonstruksi Agenda Peningkatan Kesejahteraan Petani. IAARD Press.

Junaidah, Suryanto, P., \& Budiadi. (2016). Komposisi Jenis dan Fungsi Pekarangan (Studi kasus desa Giripurwo, Kecamatan Girimulyo, DI Yogyakarta). Jurnal Hutan Tropis, 4(1), 77-84. https://doi.org/10.20527/jht.v4i1.2884

Merrifield, D. L., Dimitroglou, A., Foey, A., Davies, S. J., Baker, R. T. M., Bøgwald, J., Castex, M., \& Ringø, E. (2010). The current status and future focus of probiotic and prebiotic applications for salmonids. Aquaculture, 302(1), 1-18. https://doi.org/10.1016/j.aquaculture.2010.02.007

Rachmawati, D., Samidjan, I., \& Setyono, H. (2015). Manajemen Kualitas Air Media Budidaya Ikan Lele Sangkuriang (Clarias gariepinus) dengan Teknik Probiotik pada Kolam Terpal di Desa Vokasi Reksosari, Kecamatan Suruh, Kabupaten Semarang. PENA Akuatika, 12(1), 24-32. https://doi.org/10.31941/penaakuatika.v12i1.324 
Rosalina, D. (2014). Analisis Kelayakan Usaha Budidaya Ikan Lele di Kolam Terpal di Desa Namang Kabupaten Bangka Tengah. Maspari Journal, 6(1), 20-24. https://doi.org/10.36706/maspari.v6i1.1705

Su'udi, M., \& Wathon, S. (2018). Peningkatan Performa Budidaya Lele Dumbo (Clarias garipenus, Burch) Di Desa Serut Kecamatan Panti Kabupaten Jember Provinsi Jawa Timur. Warta Pengabdian, 12(2), 298-306. https://doi.org/10.19184/wrtp.v12i2.8118

Suryani, E., Hermanto, Saliem, H. P., Ariani, M., Suhaeti, R. N., \& Hardono, G. S. (2016). Dinamika Pola Konsumsi Pangan dan Implikasinya Terhadap Pengembangan Komoditas Pertanian [Pusat Sosial Ekonomi dan Kebijakan Pertanian, Badan Penelitian dan Pengembangan Pertanian, Kementerian Pertanian]. https://pse.litbang.pertanian.go.id/ind/pdffiles/LHP-2016-RE-ESY.pdf

Suryani, Nurjasmi, R., \& Fitri, R. (2020). Pemanfaatan Lahan Sempit Perkotaan Untuk Kemandirian Pangan Keluarga. Jurnal IImiah Respati, 11(2), 93102. https://doi.org/10.52643/jir.v11i2.1102

Verschuere, L., Rombaut, G., Sorgeloos, P., \& Verstraete, W. (2000). Probiotic Bacteria as Biological Control Agents in Aquaculture. Microbiol Mol Biol Rev, 64(4), 655-671. https://doi.org/10.1128/mmbr.64.4.655-671.2000

Yamali, F. R., \& Putri, R. N. (2020). Dampak Covid-19 Terhadap Ekonomi Indonesia. Ekonomis: Journal of Economics and Business, 4(2), 384-388. https://doi.org/10.33087/ekonomis.v4i2.179

Yanuarita, H. A., \& Haryati, S. (2020). Pengaruh Covid-19 Terhadap Kondisi Sosial Budaya di Kota Malang dan Konsep Strategis Dalam Penanganannya. Jurnal IImiah Widya Sosiopolitika, 2(2), 58-71. https://doi.org/10.24843/JIWSP.2020.v02.i02.p01

Yulianingrum, T., Pamukas, N. A., \& Putra, I. (2015). Pemberian Pakan yang Difermentasikan dengan Probiotik untuk Pemeliharaan Ikan Lele Dumbo (Clarias gariepinus) pada Teknologi Bioflok. Jurnal Online Mahasiswa Fakultas Perikanan Dan IImu Kelautan, 4(1), 1-9. https://jom.unri.ac.id/index.php/JOMFAPERIKA/article/view/14132 


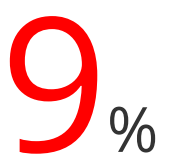

SIMILARITY INDEX

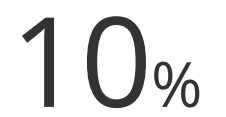

INTERNET SOURCES
$2 \%$

PUBLICATIONS
$0 \%$

STUDENT PAPERS

PRIMARY SOURCES

1 pse.litbang.pertanian.go.id

2 biologi.ugm.ac.id

3 ejournal-balitbang.kkp.go.id 